\title{
POINTS IN THE HISTORY OF THE BRAZILIAN SOCIETY OF AUTOMATICS ("SOCIEDADE BRASILEIRA DE AUTOMÁTICA" - SBA)
}

\author{
Celso Pascoli Bottura* \\ bottura@dmcsi.fee.unicamp.br \\ Carlos Eduardo Pereira ${ }^{\dagger}$ \\ cpereiradece.ufrgs.br \\ * School of Electrical Engineering- UNICAMP \\ Founder and SBA President 1983/1985 \\ Campinas SP- Brazil \\ ${ }^{\dagger}$ Department of Electrical Engineering UFRGS \\ SBA President 2009/2010 \\ Porto Alegre RS Brazil
}

\section{ABSTRACT}

The Brazilian Society of Automatics (SBA- Sociedade Brasileira de Automatica) was established in 1975 as a scientific organization to promote the Science and Engineering of Automation and Control in Brazil and to be a leading forum for researchers, students and professionals working in the various fields of Control and Automation. Currently SBA has over 700 members in Brazil (professionals, students, and organizations) and is responsible for organizing the major South-American academic event in the field of automatic control - the Brazilian Automation Conference ("Congresso Brasileiro de Automática" - CBA), a biannual event that attracts around 1,000 participants, as well as the Brazilian Symposium on Intelligent Automation (SBAI - "Simpósio Brasileiro de Automação Inteligente"). Furthermore, SBA co-sponsors events in the fields of robotics, neural networks, etc. always aiming to promote Automation and Control activities in Brazil. SBA is coordinated by a Board of Directors and a Council. It includes seven Technical Committees (Industrial Automation, Intelligent Systems, Robotics, Instrumentation, Power Electronics, Power Systems and Control Theory and Applications). SBA has one affiliated journal- "Revista Controle e Automação (Control and Automation Journal), the most important scientific jour-

Artigo submetido em 09/12/2009 (Id.: 01092)

Revisado em 23/12/2009, 22/10/2010

Aceito sob recomendação do Editor Associado Prof. Luis Antonio Aguirre nal in the control and automation area in Brazil. This paper addresses some points in the History of SBA, especially its beginnings. It is described in an oral history style, given that one of the co-authors - Celso Bottura - is one of the SBA founders.

KEYWORDS: History of technical societies, Automation, Control, Automatics, Brazil

\section{INTRODUCTION}

Motivated by an invitation by the organizers of the 2009 IEEE Conference on the History of Technical Societies, the purpose of which was to explore the history of technical societies worldwide and in order to mark the celebration of the $125^{\text {th }}$ anniversary of the IEEE, we wrote a paper [Pereira and Bottura, 2009] for that conference on the history of SBA the Brazilian Society of Automatics. In early August 2009, the co-authors of the paper, SBA President (2009-2010), Prof. Carlos Eduardo Pereira, and a founding member and former president of the organization, Prof. Celso Pascoli Bottura, presented it in Philadelphia, where IEEE was created in 1884. This was a very unique opportunity to exchange experiences with former IEEE Presidents as well as from other traditional technical societies. The importance that IEEE places on its own history, as well as the importance given by Americans to technical activities and technical people in American history, are remarkable. This article is based 
on that experience and is, therefore, written in English. It tries to summarize the most relevant facts of SBA's 35 years of existence, mainly of its beginnings. In some chapters the article will take the form of an oral history told by Prof. Celso Bottura, an eyewitness of the SBA's history. Some reflections on the future of SBA are also included.

Unlike many other countries, up to now most of the activities in Automation in Brazil have been mainly concentrated in academic circles. Certainly this is due to our level of development, to our place in the global scenario, and to our short history as an independent country (since 1822). The United States has more or less the same age, but represents a totally different situation. There is a famous Brazilian book which tries to explain some of these differences [Moog, 1981]. Our country was born after the middle ages, where and when some important arts were developed by craftsmen, with important technological consequences.

Brazil has undergone many important changes and at some point in time our activities in industries and in state-owned companies may suffer significant changes in terms of technological development. In some ways this may already be occurring. At this point the activities in our area may be considered as professionally well exercised, mainly due to foreign research, development, organization and training. Higher education in Brazil started later than it should have, mainly for cultural and political reasons. While in the United States it began around four centuries ago, and in some Spanish colonies of Latin America it was also implemented over three centuries ago, in Brazil, higher education started very slowly only after Napoleon forced the King of Portugal to emigrate to our country in 1808 and rule the Portuguese Empire from Rio de Janeiro. Up to that time Brazil was not open to the world as it certainly is today. Mainly from the late nineteenth century onwards, European and Asian immigrants started to come to Brazil, especially to the southern regions. At that time a few schools of engineering started their courses with a very strong European influence. The first Brazilian universities were only created in the twentieth century, also with a very strong European influence. Agricultural activities forced some technological development during the last century. As from 1930, industrial activities gained more impulse. In 1956 the Brazilian automotive industry, initially based on European companies, started to produce cars, trucks and tractors, becoming very important and contributing towards the general development in technologically related activities, based on American, European and Japanese companies. During that decade Brazil started some important changes, influenced by events that occurred during the Second World War. One of them, which is very important for the topic at hand, was the creation of ITA - Aeronautical Institute of Technology (Instituto Tecnológico de Aeronáutica), in São José dos Campos, one of the first higher educational
Brazilian institution inspired by the American Educational Institutions, ITA was particularly inspired on MIT - Massachusetts Institute of Technology .The first President of ITA, the American Richard Harbert Smith, 1946-1951, developed the famous "Smith Plan for ITA. The next three Presidents of ITA were also Americans. The leading Brazilian figure for the creation of ITA was Casemiro Montenegro Filho, an air force officer who visited MIT during the Second World War and realized its relevance in relation to what needed to be done for higher education and technology in Brazil. He envisioned and finally created ITA in the late 1940s. ITA started in São José dos Campos in 1950 as an Aeronautic and Electronic Engineering School, with few students, but it became the seed for great and highly important educational transformations that occurred in Brazil since then, both for undergraduate and graduate education. Graduate education in Brazil, inspired on the American Graduate Education Paradigm, started in ITA in 1961 and from then on completely changed the University Education Paradigm in Brazil. In addition, the Brazilian aeronautical industry - EMBRAER, and a very important aerospace research institution - INPE (National Institute for Space Research), among others, are located around ITA [Botelho,1999, Fischetti,2000, Morais, 2006, Silva and Fischetti,2006].

\section{AUTOMATIC CONTROL EDUCATION IN BRAZIL: THE BEGINNINGS}

In 1953, the American Edward W. Kimbark [Kimbark, 1948], an MIT Doctor and the first Dean of ITA's School of Electronics, taught the first Automatic Control course in a Brazilian engineering school to only 4 students. He was succeeded in the following years by Otto V. M. Smith [Smith, 1958 ], Professor of the University of California, Berkeley, who spent some years teaching automatic control courses at ITA. In 1957, Luiz Valente Boffi returned to ITA as a Doctor from MIT and became the first great leader of control education in Brazil. Professor Boffi organized the first group for education and research in Automatic Control of Brazil at the ITA School of Electronics. The members of Boffi's group included Rogerio Cesar de Cerqueira Leite, who became a very important physicist, Julio A. M. Coutinho [Boffi and Coutinho, 1966], Nelson Ortegosa da Cunha [Da Cunha and Polak, 1967], Wladimir Borgest [Borgest and Varaya, 1971], and Manoel Sobral Junior [Sobral, 1961; Rohrer and Sobral, 1965]. In 1970, Sobral, who after graduating from ITA received his $\mathrm{PhD}$ in Electrical Engineering from the University of Illinois, taught the first course of Automatic Control at UNICAMP (State University of Campinas) and also became the first brilliant Director of the UNICAMP School of Engineering, founding the first Automation Department at a Brazilian university, whose first head of department was Yaro Burian Junior who 
came from ITA in 1971 The department received other ITA graduates, like Hermano de Medeiros Ferreira Tavares, who later became President of SBA and of UNICAMP, Marcio Luiz de Andrade Netto, Mario Jino, Basilio Milani, Robert L. Koo, Secundino Soares Filho, Paulo Morelato França, Akebo Yamakami, Raul Vinhas Ribeiro, Jurandyr Fernandes, Ruy Albuquerque and Celso Pascoli Bottura. Other members of this Automation Department in its first years were: Manoel de Jesus Mendes, Luiz Gimeno Latre, Maria Adélia Collier Farias, Wang Binseng, Ernesto Ruppert Filho, Mauro Miskulin, Clesio Luis Tozzi, Álvaro Geraldo Badan Palhares, Wagner Caradori do Amaral, Leo Pini Magalhães, José Cláudio Geromel, Arlindo Fartes Filho and José Wilson Magalhães Bassani.

In 1963, COPPE - Coordination of Graduate Programs in Engineering was created at the Federal University of Rio de Janeiro-UFRJ, because at the time there were cultural and structural difficulties faced by UFRJ to naturally create graduate courses, as is usual nowadays at Brazilian universities. COPPE received a strong impulse from the Brazilian government, which by then had started to pay more attention to Graduate Education, particularly in Engineering. Both the government and COPPE were beginning to realize the importance of ITA initiatives in this regard. Almost since its conception, COPPE-UFRJ placed a strong emphasis on graduate education and research in the areas of automatic control, operational research and computation. Among their professors we mention Pravin Varaya, Shankar P. Bhattacharyya, Carlos Juarez Távora, Júlio Coutinho, Liu Hsu, Afonso Celso Del Nero Gomes, Eugenius Kaszkurewicz, Richard Magdalena Stephan, Edson H. Watanabe, Luiz Pereira Calôba, Sandoval Carneiro Junior, João Lizardo de Araujo, Clóvis Gonzaga, Nelson Maculan Filho, Jacques Szczupak, José Ferreira Queiroz, Alkindar Pedroso and Ronaldo Marinho Persiano.

From the 1970s onwards:

At UFSC - Federal University of Santa Catarina, Walter Celso de Lima was leading a group in Automatic Control and Biomedical Engineering that would later grow to a great extent. The same would occur in the Automatic Control area at USP - University of São Paulo, where Plínio B. L. Castrucci was the leader, at UFPB - Federal University of Paraiba at Campina Grande led by Édson Roberto Cabral da Silva, at PUC-RJ - Catholic University of Rio de Janeiro, where Pedro Magalhães Guimarães Ferreira was the leader, at UFMG - Federal University of Minas Gerais, where Ronaldo Tadeu Pena was the leader, at UFPA- Federal University of Pará, where Jurandyr Garcez was the leader and at UFES - Federal University of Espírito Santo, where Edson de Paula Ferreira was the leader.
At ITA, after Luiz Valente Boffi had left in 1966 to move to the United States, where he recently passed away, the Automatic Control group at the Electronic Engineering School was led by Nelson Ortegosa da Cunha, later by Wladimir Borgest and more recently by Takashi Yoneyama. Four classmates of Celso Bottura at ITA, who graduated in Electronic Engineering in 1962, spent all or a great part of their professional lives in Industrial Automation and Control and became important professionals in this field in Brazil: Toshiwo Yoshikai, Mauricio Kurcgant, Simão Copeliovitch and Cláudio Augusto de Medeiros Camara.

\section{A SBA FOUNDER'S PERSONAL REC- OLLECTION}

Celso Bottura, the elder author of this paper, presents here a personal recollection of some activities in Automatics in Brazil related to the origins of SBA.

In 1961, while an Aeronautical Engineering undergraduate at ITA, where at the time we did not receive any formal training in automatic control, I was fortunate to realize that my colleagues from Electronic Engineering at ITA were receiving exceptional training in Automatic Control from Professor Luiz Valente Boffi and his group. Professor Boffi was such a kind of teacher that although not teaching any class to me directly, indirectly he would become the most important teacher I ever had. By the end of 1962, I graduated from ITA and my advisor Professor Jacek Piotr Gorecki, a $\mathrm{PhD}$ from Caltech, offered me an 18-month Master of Science scholarship to do graduate work in the United States in aerodynamics. We in Brazil, at that time, even at ITA, with some exceptions, had never heard of a Master of Science degree and Graduate Studies, particularly in Brazil, but even abroad. I asked him to explain these things to me and also told him that if he could arrange me a trainee position at an American aircraft industry then I would accept his offer. Professor Jacek Gorecki kindly explained graduate studies and the MS degree and told me that the first MS Degree in Engineering in Brazil would be given in January 1963, at ITA, where graduate studies in Engineering started in Brazil. I, as an ITA undergraduate, was not aware of this. Nowadays in Brazil, where Graduate Studies at Brazilian Universities, especially since 1970, have become a very important, respected and well-known activity, it is hard to imagine the scene I described above, recalling this experience of mine. I was accepted by Purdue University where I received a MS Degree at the School of Mechanical Engineering in 1964, majoring in Propulsion, but with minors in Automatic Control and in Mathematics. I believed that this would be a good strategy to get into Automatic Control, as I had no previous background in it. At that time Professors Charles Rezek and Goodson started a graduate course in Instrumentation for Dy- 
namic Systems at the Automatic Control Group of the Purdue School of Mechanical Engineering, that was headed by Rufus Oldenburger and I fortunately enrolled on it. In addition, I became a member of the ISA - Instrument Society of America, at that time. Fortunately, when I returned to ITA, in early 1965, after an internship at Cessna Aircraft Co. in Wichita, Kansas, I had the opportunity to teach graduate and undergraduate courses in Automatic Control and Instrumentation, for students of Mechanical and Aeronautical Engineering, for the first time in Brazil. At that time there was a very important cooperation between ITA and the University of Michigan in order to create the Mechanical Engineering course at ITA. Among the American professors on this project there was Jerome Hemmye, who helped me very much in this effort before returning to the United States in mid-1965. Thanks to him some of the first ITA graduates in mechanical engineering studied Automatic Control, including theoretical and laboratory work, that I developed and taught in the second half of 1965. Subsequently, I created the Instrumentation and Control Group and the Instrumentation and Control Laboratory of ITA's School of Mechanical Engineering. Nowadays this group is called the Mechatronics Group and is led by Luiz Carlos Sandoval Góes. Two members of the initial group, Sergio Nelo Vanucci and Claudio Nobuo Takase, my former students at ITA, became important professionals in Industrial Automation in Brazil.

In 1969, the Doctorate Course in Engineering began at ITA and I decided to enroll on it. I also started to teach part time at the School of Engineering of UNICAMP - State University of Campinas, that had been recently created and was very promising. It was in an important area of São Paulo state, the most developed of Brazil, following a very important structural reformulation of our university system, during an economic boom in the country with a lot of young people seeking higher education in Brazil. UNICAMP had a brilliant president, Zeferino Vaz, who would lead it to become a highly respected and successful university.

In 1971, invited by Manoel Sobral Junior, I decided to leave ITA and move to Campinas to work full time at UNICAMP. There I created the UNICAMP Automation Laboratory and completed my PhD in Electrical Engineering in 1973, having Yaro Burian Junior as my advisor. In my $\mathrm{PhD}$ thesis [Bottura, 1973], the important contributions were in chaos and its control in chopper control of de series motors. As the word chaos was not clearly established and chaos theory in this sense was still to be developed and become accepted, instead of chaos, we formally called it pseudo random oscillations or the Pulkin-Birkhoff phenomena [Birkhoff, 1932, Pulkin, 1950]. References were scarce. I consulted the IEEE Transactions in the early 1970s and found nothing on this subject. University libraries in Brazil were very poor, with the exception of the ones of ITA and COPPE-UFRJ, that were reasonable. There was no Google, no Wikipedia, no Internet, and no qualified professional services in Brazil to help you in your research for references as there are today. There were a few theses by students of Christian Mira from the LAAS - Laboratoire d'Automatique et d'Analyse de Systèmes, Toulouse, France, and Andronov's book [Andronov, Vitt and Kaikin, 1966; Aubin and Dahan, 2002; Mira, 1990; Mira, 1997]. I still think our contribution in my $\mathrm{PhD}$ Thesis was very original and useful. We were influenced by a research project we had with the Subway Company of the City of São Paulo - Companhia do Metropolitano de São Paulo, who was building the first subway system in Brazil with Westinghouse's Technology (the same technology used in the BART subway of San Francisco that was also under development). During this project, we confirmed that Westinghouse limited the pulse width of the PWM control system, probably for empirical reasons, a result that we were able to obtain theoretically in 1973, to avoid chaotic oscillations in the chopper control system that might create, for instance, communications problems. For studying and controlling this kind of chaotic instability, we were able to create a nonlinear implicit difference equation model to demonstrate it and to control it for the chopper controlled dc motor, a hybrid control system in modern day parlance. At the 1977 JACC - Joint Automatic Control Conference, in San Francisco, we presented our results [Bottura, 1973; Burian Jr and Bottura, 1977a ], as well as related results at the 1977 - PESC - Power Electronics Specialists Conference, in Palo Alto [Bottura, 1973; Burian Jr and Bottura, 1977b ]. After that first presentation in the United States, we tried to publish this important and original result on chaos and its control in the IEEE Transactions on Automatic Control. We received three revisions, one was very good, one reasonable, and a third revision that was completely incorrect and inadequate. This third revisor said something like the following nonsense: "the problem we treated has already been solved in the book "Inners" by Jury" [Jury, 1974]. I always respected Jury's brilliant work; he is an important reference in books I wrote [Bottura, 1982a; Bottura, 1982b; Gertler, 2006]; and I even have a paper [Bottura and Ferreira, 1993] published in a book dedicated to him [ Jamshidi, Mansour, Anderson and Bose,1993]. But the book on "Inners" was on linear systems, with other objectives, and I already knew since the early 1970s that chaos may only occur in nonlinear systems. So the reviewer was completely wrong. To this day I do not know how to proceed in such situations where peer reviewers say things that do not make sense and result in having your paper refused. In this first experience I made no complaint. That paper might have been the first on chaos and its control in the IEEE Transactions on Automatic Control. Unfortunately, at least for me, this did not occur. Certainly all of us have bad experiences with bureaucracy and with reviewers and although now retired and seventy two years old, I still feel the need for some orien- 
tation and regulation for these situations, where inadequate misunderstandings happen. As the IEEE is now more than 125 years old, maybe for the next generations, for its very important transactions, and for our profession and contributions, some effective procedure to deal with these misunderstandings can be developed and explained to our community [Pereira and Bottura, 2009]. SBA should also consider these situations and have an adequate and ethical procedure to deal with these misunderstandings when really necessary.

\section{THE FOUNDATION OF IN 1975}

In 1974, Prof. Celso Bottura succeeded Yaro Burian Jr. as Head of the Automation Department of UNICAMP. Since the early 1970s some doctorate courses were created in Brazil at UNICAMP, UFRJ, USP, shortly after ITA's initiative in this direction in 1969. As Professors Castrucci and Bottura wrote in the Presentation of the Encyclopaedia of Automatics - Enciclopédia de Automática [Aguirre, 2007], conditions were created in Brazil for the creation of a Scientific Society in the Automation area in Brazil at that time. Certainly many of us thought about this possibility and some had even tried in vain to create such an organization.

At that time the word InformaticsInformatique in French and Informática in Portuguese was very important to describe the area of Computation in Brazil. In 1967, the French had created the IRIA - Institute de Recherche in Informatique et Automatique - Research Institute in Informatics and Automatics, nowadays the INRIA, that I visited in September 1974 [ Bittanti and Gevers, 2007 ]. The International Federation of Automatic Control - IFAC had its Journal called Automatica.

So we considered that Automatics (Automática in Portuguese) could be the best word to describe the Science and Engineering of Automation and Control, in analogy to the names of other areas of engineering and science as mechanics, electronics, physics, mathematics (respectively mecânica, eletrônica, física, matemática in Portuguese). The word Mechatronics had not been invented at that time, and we understand that the word Automatics is more general and inclusive for the area of Automation and Control.

In January 1975 I made an appointment at the Department of Electrical Engineering at the University of São Paulo, Polytechnic School of Engineering - USP (Poli-USP) with Plinio Benedito de Lauro Castrucci. We did not know each other personally, but he had written the first book on Automatic Control in Brazil [Castrucci, 1969; Gertler, 2006]. We understood each other, became friends and decided to create the Brazilian Society of Automatics - Sociedade Brasileira de Automática - SBA. Plinio Castrucci had experiences both as a University Professor and as an Industry Creator and Owner in the area of Automation and Control. He had cre- ated Amplimag, some years before, a pioneering and well known automation company in Brazil at that time. Combining our experiences and personal relationships with other professionals in the area in Brazil and after some red-tape to set the formal basis for it, we managed to create SBA on June 5th, 1975 in a Founding Assembly at the Poli-USP in São Paulo city, having Plinio Castrucci as the President and myself, Celso Pascoli Bottura, as the Vice-President for the term of 1975-1977. SBA was established as a scientific organization to promote the area of Automatic Control in Brazil in its widest sense, and to be a leading forum for researchers, students and professionals working in the various fields of Control and Automation. Coordinated by a Board of Directors and a Council, SBA was created to be the Brazilian National Member Organization of the International Federation of Automatic Control - IFAC and this is explicitly stated in its Constitution, approved at its Foundation Assembly, which was attended by a massive number of SBA founding members, including many engineers of the "Companhia do Metropolitano de São Paulo”. The affiliation to the IFAC was formalized shortly after the creation of SBA.

\section{THE FIRST YEARS OF SBA}

The first event SBA organized was the "First Week of Technical Lectures" in November 1975 at Poli-USP. In November 1976, having Plinio Castrucci as President of the Organizing Committee, the First Brazilian Conference on Automatics - Congresso Brasileiro de Automática - CBA was held at USP. Since then the CBA is held every two years and became the largest South American academic event in the area of automation and control. The second CBA occurred in Florianópolis, organized by Walter Celso de Lima of UFSC, the third CBA took place in Rio de Janeiro, organized by Liu Hsu of UFRJ, and the fourth in Campinas, organized by Celso Bottura.

The second SBA's Board of Directors elected for the period 1977-1979 was headed by Antonio Salles de Campos Filho, from ITA, and Celso Bottura continued as Vice-President. After his first year, for personal reasons, the President resigned and Celso Bottura assumed the position of President. For the third and exceptionally for the fourth Board of Directors, Walter Celso de Lima was elected SBA's President. For the fifth, Celso Bottura was elected for the period 1983-1985.

In 1984, SBA together with the Argentinean Society of Automatic Control, AADECA - Associacion Argentina de Control Automatico and the Chilean Society of Automatic Control - ACCA - Associacion Chilena de Control Automatico, organized the First Latin-American Conference on Automatics- Congresso Latino-Americano de Automatica, held in Brazil. Since then, every two years the LatinAmerican Conference on Automatics has been held. The sec- 
ond was held in Argentina in 1986, the third in Chile in 1988, the fourth in Mexico organized by AMCA - Associacion de Mexico de Control Automatico, in 1990, the fifth in Cuba, organized by CONAI - Commission Nacional de Automatizacion Industrial in 1992. In 2010, the XIV Latin-American Conference in Automatics was held in Santiago, Chile, and both authors of this paper participated of the meeting of the Latin American Council on Automatics, created in 1982, at the same city. SBA has already been responsible for three of these events: 1984 in Campina Grande, 1994 in Rio de Janeiro and 2006 in Salvador. Only in 1991 would the First European Control Conference occur and in 1994 the First Asian Control Conference occur [Thoma and Patton, 1995]. We still lack a Pan-American Control Conference for our America Continent.

In 1985, organized by Acher Mosse from the Electrical Energy Research Center - CEPEL - Centro de Pesquisas de Energia Elétrica, the first IFAC International event sponsored by SBA, the IFAC Symposium of Planning and Operation of Electric Energy Systems was held in Rio de Janeiro.

For the sixth Board of Directors, for the period 1985-1987, Atair Rios Neto from INPE was elected SBA's President. He created the SBA Journal: "Controle e Automação" - Automation and Control, that became the most important scientific journal in the field of Automation and Control in Brazil, with 6 issues published per year. Wagner Caradori do Amaral from UNICAMP was its first editor for the period 19871989. After him the editor was José Cláudio Geromel, from UNICAMP, for the period 1990-1991, then Rafael dos Santos Mendes, from UNICAMP, for the period 1992-1995, Oswaldo Luiz do Valle Costa, from USP, for the period 19961999, João Bosco Ribeiro do Val, from UNICAMP, for the period 2000-2004 and Ricardo Ribeiro Gudwin, also from UNICAMP, for the period 2004-2008. Recently Luis Antonio Aguirre, from UFMG, became the new Editor-in-Chief, and jointly with Alexandre Bazanella from UFRGS and José Raimundo de Oliveira from UNICAMP form a Board of Editors for the journal.

For more details about the first years of the SBA and its CBAs see [ Lima, 1987; Castrucci and Kaszkurewicz,2002].

In 1993, during the Presidency of Pedro Guimarães Ferreira from PUC-RIO, Marcio Rilo from USP, who unfortunately passed away still young in 2010 and that would be the eleventh President of SBA, organized the First Brazilian Symposium on Intelligent Automation - SBAI - Simpósio Brasileiro de Automação Inteligente, in Rio Claro. SBAI is a biannual event sponsored by SBA to take place in the odd years when there is no CBA. The second SBAI occurred in Curitiba in 1995, the third in Vitoria in 1997, the fourth in São Paulo in 1999, the fifth in Canela in 2001, the sixth in
Bauru in 2003, the seventh in São Luis in 2005, the eighth in Florianópolis in 2007 and the ninth in Brasília, in 2009.

\section{SBA TODAY}

As already mentioned, SBA was created in 1975 with the following mission statement: "to promote in Brazil the Science and Engineering of Automation and Control- in all types of systems, mechanical, biological, economical, social, ...". SBA's vision was to become the leading forum for Brazilian researchers, students and professionals in the area of control and automation, collaborating with major international technical societies such as IEEE and IFAC. Thirty-five years after its creation, the society has already become the most important Brazilian technical society in the fields of automation and control, with more than 1,000 active participants in its activities. SBA's main activities include:

- Conference organization: SBA is responsible for the major Brazilian conference in the area of automation (i) the "Brazilian Automatics Conference (in Portuguese "Congresso Brasileiro de Automática" - CBA), which takes place every two years on even years and is usually attended by over 1,000 people and (ii) the Brazilian Symposium on Intelligent Automation (in Portuguese "Simpósio Brasileiro de Automação Inteligente" - SBAI), which also occurs biannually but on odd years and discusses topics such as neural networks, fuzzy logics, genetic algorithms and other similar techniques for industrial automation applications.

- Publication of the journal: "SBA- Controle $e$ Automação", with 6 issues per year and 12 papers per issue, which has become the most important scientific publication in the area of control and automation in Brazil.

- SBA is organized around Technical Committees and there are currently 7 committees: Industrial Automation, Intelligent Systems, Robotics, Instrumentation, Power Electronics, Power Systems, and Control Theory and Applications, and a new one in Engineering Education is being formed

Administratively, SBA is managed by a Board of Directors, composed of four members (President, Vice-President, Treasurer, Secretary), and an Advisory Board with 6 members. All members are elected by SBA members for a twoyear mandate. One of SBA's recent important results, with the contribution of most of the Technical Committees and several of its members was the publication of the first 3 volumes of the "Enciclopédia de Automática - Controle e Automação" ("Automatics Encyclopedia - Control and Automation”) [Aguirre, 2007], which includes 1,544 pages, 
with chapters written by more than 100 Contributors from 27 Brazilian Institutions. This work constitutes a comprehensive reference book in the area of control and automation accessible to students and professionals.

\section{CONCLUSION}

This paper has presented some aspects of the history of the Brazilian Society of Automatics - SBA, from its creation in 1975 to 2010. Despite being relatively young, SBA has already achieved a leading position in South America as a technical society in the area of Automatics-the Science and Engineering of Automation and Control.

Looking to the near future, SBA aims to address the following questions:

- How can we motivate an increasing number of young people to become engineers in order to fill the so called "engineering gap" which is appearing in countries such as the U.S and Brazil?

- How can we increase the participation of student members in SBA?

In order to address such challenges, SBA, together with other Brazilian organizations, is supporting initiatives such as the "Brazilian Robotics Competition- CBR http://www.cbr09.fei.edu.br/. Additionally, several SBA student chapters, called "SBA Jovem" ("Young SBA) are being created all over the country. From our experience on writing this article and on our participation in the 2009 IEEE Conference on the History of Technical Societies, some reflections that could be important for the future of SBA are:

- We should have Professional Historians doing research on the History of SBA as soon as possible.

- We should reflect on the present and the future of SBA, and write about it.

- From talks with members that dedicated a great part of their lives serving IEEE, it became clear to us the importance the American Companies gave to the participation of their profissionals in the activities of Technical Societies. They even paid the IEEE membership dues for their employees. We should be aware of this and learn from it.

- We should emphasize the interactions with IFAC and IEEE.

- Our National Conferences as well as the LatinAmerican Conference in Automatics are very important.
- It would be important to create the Pan-American Conference on Automatics as soon as possible.

- It is important to continue the development of the "Enciclopédia de Automática".

- We should increase the number of editions of our Journal "SBA - Controle e Automação" as well as create new Journals in our areas of interest.

\section{REFERENCES}

Aguirre, L.A.(Ed.) (2007) Enciclopédia de Automática, Vols 1,2,3. Editora Blucher, São Paulo.

Andronov, A. A., Vitt, A. A. and Khaikin, S. (1966) Theory of Oscillators. Pergamon Press.

Aubin, D. and Dahan, A. D.(2002) Writing the History of Dynamical Systems and Chaos: Longue Durée and Revolution Disciplines and Culture.Historia Matematica, vol. 29. pp 273-339.

Birkhoff, G. D.(1932) Sur L'Existence de Regions D'Instabilité en Dynamique. Annales de L'Institute Poincaré, pp 369-386.

Bittanti, S. and Gevers, M.(Eds.) (2007) On The Dawn and Development of Control Science In The xx-th Century. European Jornal of Control, Special Issue, vol 13, n 1, January-February.

Boffi, L.V. and Coutinho, J.A.M. (1966) Elementos de Análise de Sistemas Lineares. Etegil, São Paulo.

Borgest,W. and Varaya,P. (1971) Target Approach To Linear Pursuit Problems. IEEE Transactions on Automatic Control, vol AC-16, n 5, pp449-459.

Botelho,A.J.J. (1999) Da Utopia Tecnológica aos Desafios da Política Cientifica e Tecnológica: O Instituto Tecnológico de Aeronáutica (1947-1967). Revista Brasileira de Ciências Sociais, vol14, n 39, São Paulo.

Bottura, C.P. (1982a) Analise Linear de Sistemas. Editora Guanabara Dois, Rio de Janeiro.

Bottura, C.P. (1982) Princípios de Controle e Servomecanismos. Editora Guanabara Dois, Rio de Janeiro.

Bottura, C.P. (1973) Contribuição ao Estudo do Controle de Torque em Máquina Serie por Modulação em Largura de Pulso. PhD Thesis, UNICAMP.

Bottura, C.P., and Ferreira, N.A. (1993) On The Optimal Control of Linear Discrete- Time Systems With Rational Expectations. Published in Reference [Jamshidi, Mansour, Anderson and Bose, 1993] , pp 211-217. 
Burian Jr, Y. and Bottura, C.P. (1977a) Stability of Periodic Oscillations in Proportional Chopper Control of a Series Motor. Proceedings of the 1997 JACC- Joint Automatic Control Conference, San Francisco, CA, USA, vol.2, pp 964-969.

Burian Jr, Y. and Bottura, C.P. (1977b) Feedback Chopper Control of Series Motor on the Regenerative Braking Mode. Proceedings of the 1977 IEEE- PESC- Power Eletronics Specialists Conference, Palo Alto, CA, USA, vol. 1, pp 286-289.

Castrucci, P.B.L (1969) Controle Automático: Teoria e Projeto. Editora Edgar Blucher, São Paulo.

Castrucci, P.B.L, and Kaszkurewicz, E. (2002) Os 25 anos da Sociedade Brasileira de Automática. Revista SBA: Controle e Automação, Sociedade Brasileira de Automática, vol.13, no 1 .

DaCunha, N. O. and Polak, E.(1967) Constrained Minimization Under Vector Valued Criteria in Finite Dimensional Spaces. Journal of Mathematical Analysis and Applications, vol 19, no 1, 1967.

Fischetti, D. (Ed.)(2000) Instituto Tecnológico de Aeronáutica -50 anos. ITA.

Gertler. J. (Ed.) (2006) Historic Control Textbooks. International Federation od Automatic Control/ Elsevier.

Jury E.I.(1974) Inners and Stability of Dynamic Systems, Wiley.

Kimbark. E.W. (1948) Power Systems Stability, 3 vols. Wiley 1948/IEEE, 1995.

Jamshidi, M.; Mansour, M.; Anderson B.D.O. and Bose, N.K. (Ed.) (1993) Fundamentals of Discrete Systems A Tribute to Professor Eliahu I. Jury. TSI Press, Albuquerque.

Lima, W.C. (1987) 10 Anos de Produção Cientifica em Automação no Brasil. Revista SBA: Controle e Automação, vol.1, no1, pp3-10.

Mira, C. (1997) Some Historical Aspects on Nonlinear Dynamics, Possible Trends for the Future. International Journal of Bifurcation and Chaos in Applied Science and Engineering, vol.7, pp 2145-2173.

Mira, C. (1990)Systèmes Asservis Non Lineáires, Hermès. Paris, 1990.

Moog, V. (1981) Bandeirantes e Pioneiros 13th Edition. Editora Civilização Brasileira.
Pereira, C.E. and Bottura, C.P. (2009) The Brazilian Society of Automatics-SBA("Sociedade Brasileira de Automática -SBA"). The 2009 IEEE Conference on the History of Technical Societies, Philadelphia, Pennsylvania, USA.

Pulkin, C.P. (1950) Oscillating Iterated Sequences. Doklady Akademi Nauk, USSR, vol.73, no6, pp1129-1132.

Rohrer, R. A. and Sobral Jr. M. (1965) Sensitivity Considerations in Optimal Systems Design. IEEE Transactions on Automatic Control, vol AC10, no43, pp 43-48.

Silva,O. and Fischetti, D. (2006) Casemiro Montenegro Filho. Bizz Editorial, São Paulo.

Smith, O.J.M. (1958) Feedback Control Systems. McGraw Hill.

Sobral Jr., M. (1961) Minimizing Effects of Disturbing Signals Through a Minimum Square- Error Criterion. IRE Transactions on Automatic Control, vol AC-6, no3, pp 306-311.

Thoma, M. and Patton, R.J. (Ed.) (1995) Proceedings of the European Science Foundation Workshop: Control of Complex Systems. La Sapienza, Rome, 6-7. 